\title{
Changing Incentives and Opportunities for Risk-Taking in Recent U.S. Banking Industry
}

\author{
SEOK WEON LEE
}

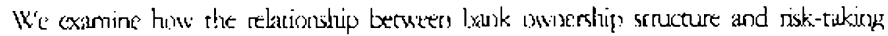
may ix differenty affected by the deffreot reyulatury resunes in the L'S banking industry. W'e find that hizher insider-ownership banks bad greater risk-taking

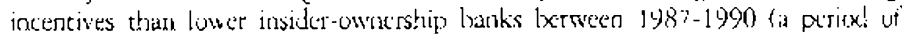
relaive deregulacions and decline of the U.S. hanking industry), when we represeat risk-taking by swstcnatis risk. Howeser, this grater systemarjo risk-takking is

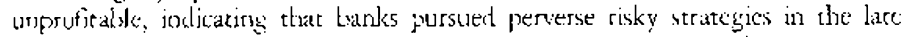
$1980 \mathrm{~s}$ is suggested by the moral-hazard hypothesis in banking liferature. But we find that grearer systemaric risk-tuking incenzives of higher insiter-uwnersbip banks than kower insider-ownerstajp banks disâylyared, and that the association benxem risk-taking and protitability improvert over the period of tightened regulariun 11991-1995). These results may uffer some slipporting eviderrice fior the efferriscness

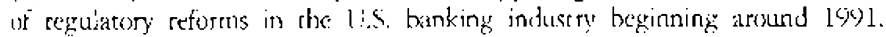

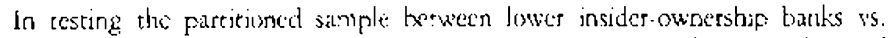
highter unes, we find that tle jositive reliationsthp betwern insider ownership) and nisk-taking, and the negariwe relattonship berwetel the risk-liking ansl proficabiliti;

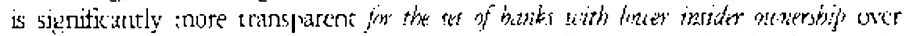

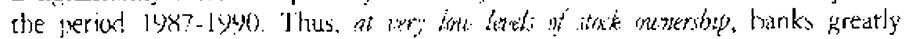

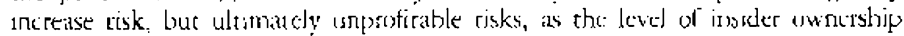

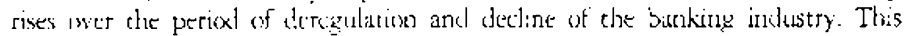

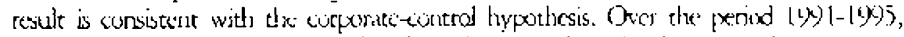

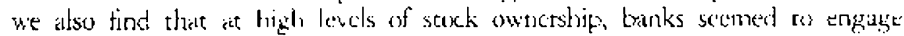

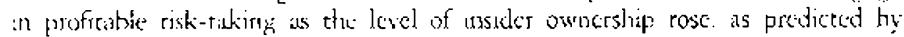
ilec corporace-control hypothesis.

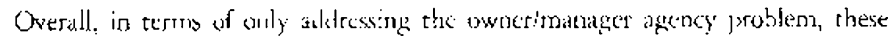

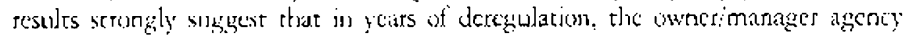

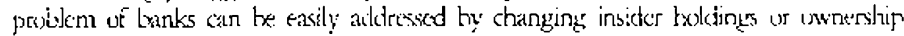
scructure (e) aiconnmodate incressised risk. But this posticy suggestion should be

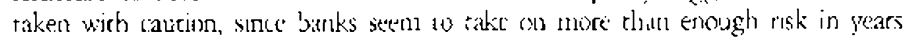

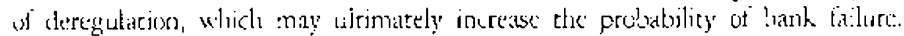

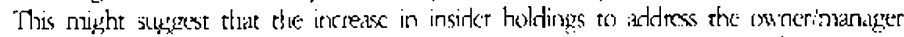

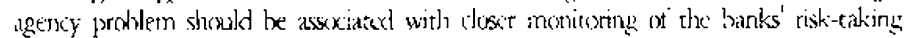

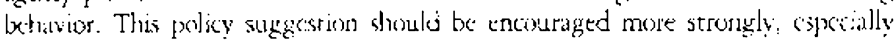

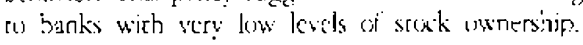

Kent(i)rlds: agency problems, insider owncrship, bank regulations, risk-taking, corporate contrul

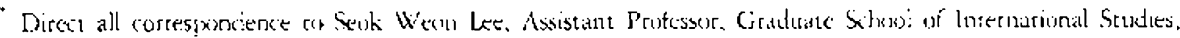

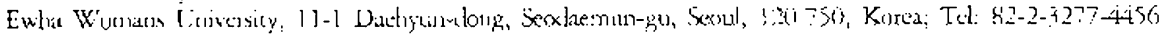

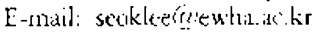




\section{INTRODUCTION}

B

anking literature has emphasized a number of agency problems, or the conflier. of interest betwoen managers and outside stuckholders. As in non-financial corporations, limited liability gives bank stuckholders an incentive to exproprate wealth from debt holders (crecticors) by increasing risk. But in banking, creditors have weak incentives to monitor and constrain anch risk-caking because they are protected by deposit insurance. It creditors provide the major funding, so that only a negligithle part of toral funding comes from stuckholders, incentives for risk-taking will be all the greater.

Many studies, howcver, suggest that the incentives of managers may differ from those of outside stockholders. If manalgers' wealth is largely in nondiversifiable human capital (firm-specific) form, and mankagess of fialed firms have difficulty finding comprarable jobs due to bad reputations regarding their management abilities, they may act in a risk-avctse rather than a value-maximizing manner regarding stockbolders to presere jobs and perquisic consumption from control of the firm. In this case, their optimat legree of risk-taking would be less rhan that desired by outside stocklodelers. Denis (2001) provicted simple examples of agency cost that includes managers congaging in activitics that directly benefit themselies such as managerial shirking (golf gancis) and managerial consumption of perpuisites (plush offices, expense account mats, corporate jets, ace). These actions may also bencefic shareholelers. But if they do not, the cost is bornc by shareholders. Shareholders, anticipating such problerns, will discount the price of shares. In this manner, agency costs are borne by the original sharehokders.

This owocrimanager ageocy problem of the contlicts between stokklokers and managers, however, can be mitigated it managers' interests (objects) are aligned with those of oursicle stockholders. Onc way in which alignment of interest may occus is through insider (managerial) ownership of the firm's stok. Several previous studies exannined the relationship between risk-taking and the degree of insider ownership. Saunders. Strock, ant 'fravlos (1990) found that stuckhulder-controlled banks (banks whose manatgers hold a relatively large proportion of (xe bank's stocks) have greater incenrives to take risk thin managerially-controlled banks thanks whose managers hold a relatively small proportion of the bark's stocks). Densetz, Saidenberg, and Strahan (1997) find that the relationship between insider ownership and risk-taking is significantly positive only at low charter value banks - those whose moral liazard problems are most severe and where contlices between uwners and managers risk preferenes, are

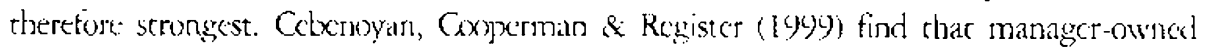
thrifts extrihited unprofeable tish-laking in the nid-1980), years of regulattory laxicy and low charter values, bue demonstrated protitable rist-taking in the mist-1900, a period of regulatory stringency and high charter values.

Mork, Sleterer and Vishny (1488) found that 'Inbin's q increases as insider ownership increases up on $5 \%$, then a fatls as insider ownership) grows up to $25 \%$. linally, q again increases ac higher insider ownership levels. Mf(conmel and Servates (1990) 
found a similar result. Researchers (includinge Gorton and Rosen, 1995) interpret these results in terms of the entrenchment power of managers, for small insider ownership, mantigers do not have enough prower to be entrenched. Thus, incentives of managers could easily be aligned wirh those of outsicte stextholders as insider ownership increascs. As insider ownership continues to rise, ranangess would have cnough power to be entrenched: managers would have enough ability to resist monitoring rather than aligning their interest with those of utside stockholders, but managers still do rot have cnough shares to have the same objectives as outside stockholders. A further increase in ownership could align management interest with outside stockholders: managers cssencially berome the sole owners.

More recently, revicws of the evidence on insider ownership are found in the works of Holderness (2001) and Denis (2001). The evidence on the relution between insider owinership and firm performance is mixed. Denis $(2001)$ finds that these exists evidence that firm performance first increases and then aleceases with percentage ownership, suggesting that the incentive alignment effect of increased onenership is more important at lower levels of maragerial ownership while the entsenchment effect dominates at somewhat higher levels. Huglics ct al. (2003) finds that the effects of an increase in insider ownership have two basic effects; (1) an alignnent-of-incterests effect; and (2) a contrasting entrenchmetor effect.

Celonoyan, Coopcrman and Register (1999), and Saunders, Strock and Travks (1990) argue that uwncrshp structure may have a more powethl effect on the risk-takitge incentives of banks diring periods of deregulation relative to periods of regulation. Unlike non-banking firms, the presence of regulators may either accentuate or mitigate bank risk-taking incentives. In periods of bank activity and interest-rate deregulation or closure-rule forbearance, bank stockholders, atwir forlizs, have greater incentives and ability to increast risk than when regulations are tight and strictly enforced. In other words, clarng periuds of deresulation and regulator forlearance, the ability of steckholders to maximize the value of their call and put options by grcater risk-taking is entanced.

The period between the late 1980 s and the carly 1400s is wedely ackowaledged to have been a period of significant regulatory changes in the recent L.S. hanking indestry, as the transition from a deregulated period (pre-199) to a regulated period (post-19(1)). Rescatchers generally ayree that the mord havard associated with fixed.rate deposit insurance system and the Eederal Deposin misurance Corporation's (FDIC) "forbarance" practiced in the 1980 s played major roles in the bank failure of the late $1980 \mathrm{~s}$. These problems motivared a major regulatury change in the banking industry beginning around 19y. The major reforms leyislated with the BDICIA in 149 I include: the abandonnent of forlowanke, the introducrion of risk-basced deposit insurance promiums, the linnitations on the use of "tox-big-to-fail" bailouts, and extended fecderal regulation sover forcign bank branches and ingendies.

This suldy corrinues the atwoe line of resedrch and investigates those issues simultadneously, i.e. the effect of insider ownership in acklessiogs agency problemes, entrenchment 
effects in ownership structure litcrature, and how these problems are related to the rcgulatory regimes surrounding the banking induscry. 'This is done by examining how the relationship betwetn bark ownership strucuure and risk-taking may be differcntly affecred by different regulatory regimes. More importantly, we test these hypotheses by clecomposing the risk measure into two parts: (1) the systematic (market-related); and (2) the unsystematic (non market-relatcd) risk, believing that the systematic risk is more appropriate to the hypotheses being examined.

From the full sample teats, we find that the higher insider-ownership banks have greater risk-taking incentives than lower insider-ownership banks during the period of relative deregulation (1987-1990) when we represent risk-taking by systematic risk (beta of hanks' stock returns, as estimated by the one-factor market model), but not when we represent risk-taking by unsystematic risk (standard deviation of errors from the market model). We believe that systemaric risk is more appropriate to the fundannontal ideas being examined since the risky assts in the sample banks' portolios are loans to large businesses, and the risk of these loans largely depends on the cconomy at large, as reflected in the general course of the stock market. However, this greacer systematic risk-taking is unprofitable (where profitability is measured by the return on assets). This indicates that the banks pursued perversc risky strategies in the late 1980 s as suggested by the moral-hazard bypothesis in the banking literature. Inder closure-rule forbearance and fixed-rate leposit insurance premiums, bank managers and stoxkholders do not need to deliberately pursue risk-taking stratcgies. They may rely on lucky outcomes, without being accurately informed about their investment projects and tucure prospects of their banks. Taking chances and hoping for good luck (taking on high variance projects and hoping for economic boom), of course, occasionally yield high earnings. However, the probability that the outcomes turn out to be bad will increase. These results may collectively provide robusr evidence that support the premises of the previous studies assuciated wirh banking lircraturc on moral hacard and ownership scruccure.

$\Lambda \mathrm{s} n$, we find that greater systematic risk-taking incentives of higher insider-bwnership, banks vs. lower insider-ownership banks disappared over the period of tightened regulation (1991-1995). This result, of course, mily deductively indicare that bankers believe that the FIIC, and other regulators would increase the relative frequency of examimation for higher insider-ownership banks during the poriod of rightened regulation. But more importantly, these results may offer some evidence for the effectiveness of the regulatory reforms begirming around 194l. Risk-based deposic insurance promiums are particularly interesting because under risk-based deposit insurance premiuns, insurance premiums inctease with the level of risk-taking and constequent deteriorating of assct quality. Thus, banks risk-taking insentives are expected to decrease under risk-based deposit insurance premiums, if they are well closeth. Rewarding the association of risk-taking with profitability, we find that the association has improved over the period 1991-1995, again supporting the offectiveness of the regulatory reforms. Compared to fexed-rate deposic insurance premiums, barkers will andyac their investment 
project more accuratcly and deliberatcly and undertake it if they are pretty uptimistic about its high earnings, which will resule in a higher probability of good outcomes and profitability under risk-based deposit insurance premiums. That is, after regulatory reforms, current high levels of risk would be beter associated with subsequent good performance compared tos the pre-reform period.

Overall, in terms of only addressing the ownerimaniger agency problem, the above resules from the full sanple tests strungly suggest that in years of deregulation, the owner/manager agency prolilem of banks can $b$ casily addressed by changing their insider holdnges os ownesship structure that accommodate increascel risk. But this policy should be taken wery autiously, sine banks seen to take on more than enough risk in years of deregulation. 'I his may ultimately increase the probability of failure of banks. This might suggest that the increase in insider holdings that adderss the ownerimanager agency problem should be assuciated with closer monitoring of the banks' risk-taking behavior.

In the test for the partitioned sample berween lower insider-owership banks is bigher ones, we exanine more explicitly the curporate-control hyporbesis, which states that during periods of decline for banking industry, banks with entrenched managers at low levels of stock onnership will engage in greater, but unprofitable, risk-taking, and manager-owned hanks will engagre in profitable risk-taking. Wh find that the positive relationship between insider ownership and risk-taking, and the negarive relarionship, between risk-taking and profitability, is significantly more cransparent for the st of bathk with lenet insider on nerbif between 1987-1990. a pertiud of dexegulation and decline of the banking industry. Thus, at ewy line tetels of stock atworshop, the banks greatly increase risk, but to their detrinient, as the level of insider axnership riscs over the period of deregulation and clecline of the banking industry. This result is consistent with the corporatc-control lypothesis. Between 1991-1995, we also find that at high latels of stsck satyerstip, the banks seem to engage in profirahle risk-taking as the level of insider ownership rises, as predicted by the corporatecontrol hypothesis. The tesults fron the partitioned samples provide stronger evidence than in the full sample tests for the hypotheses, especially for the banks at very low levels of stork ownership, and we may have to give strunger policy sugergestions to these banks.

In the axext section, we describe the simple of banks. Section i describes the testing mextel of the hypotheses. Section 4 presents the emprivical results, and section 5 offers concluding comments.

\section{SAMPLE AND DATA}

The simple for this study consists of $6 ?$ bank holding companies for which data are awailable on Standard \& Poor's Stock Report, the (enter for Rescarch in Sccurity' Prices (CKSP) data tapos, and Bark Proxy Statement data butweer 1987-1995' lrom 
the Standard \& Poor's Stock Report, we obtain the capital-to-asset ratio, book value per share, asset portiolio shares, and asset size for each company. liom the CKSP database, we obrain the daily stoxk return data (daily returns are adjusted to account for dividend payouts and stock splits). From the Bank Proxy Statement data, we ubtain an insider ownership variable onealsuring the shares held by offeces and directors of the banks as a fraction of shares outstanding.

\section{SPECIFICAIIION OF THE TESTING MODEL}

We use the following model to examine the relationship between insider ownership and risk-taking for banks:

Risk $=f$ (inssider uwnership, capital-to assec ratio, thaster value, asset size, economic growth)

where, risk for cach individual bank is proxicd by the systematic risk measured by the beta of hank's stock returus, and unsystemaric risk is measured by the standard deviation of errors from the one-factor market model.

Insider ownership is the percentage of the equity held by officers and discotors of a bank. We include capital-to-abset ratio, narket-to-book equity ratjo ( $q$ ratio), and asset size as control variables affecting the risk-taking behavior of banks. To control for leverage effect on risk, we include the banks' capital-to-asset ratio. We use the bank's book value of capital-to-asser rario, since this is the leverage measure most commonly monitored by regulaturs. The market-co-bonk equity ratio of a hark is used as a measure of its charter value reflecting the counumic valuc of fucurc growth opportunity. A bank with a high charer value has an incentive (6) avoid risky strategies, since the owners of the bank cannot sell the charter if the hank is declared insolvent. We include the bank asset size as another control variable affecting the risk-taking behavior of hanks. Wo include the Ginp groweth rate to conteol for the impact of economic conditions on the banks risk-taking incentives. Following Gaunders, Serock and Travlos (1990), we are assuming that wrership structure is exogenous and the level of risk-taking is condogenously determined. That is, the level of insider ownership is the driving variable, and risk is the result. But, a bank's risk may affect its ownership structure. We address this simulaneicy problem by lagging the insider uwnership variable in tur regression equatiuns:

'lable 1 preserrs summary statistics of the sample banks. The banks in the sample range from $\$ 235$ million to $\$ 250$ billion in assets, averaging $\$ 3.5$ billion. The average (apital-to-asset ratio is $7.2 \%$. Out measure of charter value averages 1.03 , ranging from 0.88 to 1.52 . Insikder ownership averages $13 \%$ of the outstanding shares of the sample banks, ranging from 0 to $71 \%$. 
Table 1. Summary Statistics

\begin{tabular}{|c|c|c|c|c|c|}
\hline & Mcan & Median & Maxinium & Minimunu & Standiard-deviation \\
\hline Asers (Sisilliuni) & 7.5 & 2.7 & 250 & 0.235 & 22.64 \\
\hline 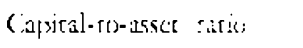 & 7.2 & 6.8 & 14.95 & $?$ & 0.02 \\
\hline Market-to-buok r:acis) & 1.03 & $0 . x$ & 1.52 & 0.88 & 0.06 \\
\hline Insidur uwoutsit:p, & i). $1 \%$ & 0.11 & (0). $₹]$ & () & 0.14 \\
\hline N'untee: of observarions & 598 & & & & \\
\hline
\end{tabular}

To summarize. We use the panded data to cstimare the following equations over two different regulatory regimes in recent L.S. banking industry, 1987-1990 vs. 195)1.1995. To cxamine whether the effect of insider ownership on reducing agency problems or on aligning the intcrests of managers wirh those of stockloblers may be different depending on the degres of regulatory scrength of the bankinge industry, we partitioned the whote sample into the two sub-samples: 1) 1987-1990, a period of dercyulation; and 2) 1991-1995, a jeriod of tirhtened regulation. We include rime-fixed effects to control for thanges in the awerage level of risk common to all banks in the sample, and estimate a random effects nodd to control for cime-invariunt bank-specific lactors relatisig to risk.

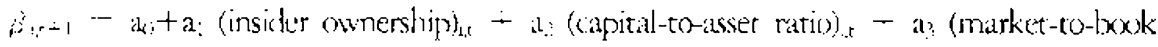

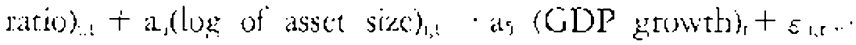

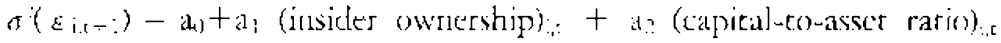

$$
\begin{aligned}
& + \text { a. (market-to-book maciol. }+ \text { ai }(\log \text { of issct sizc) } \\
& \text { tas (GDP sroweth) : } \varepsilon_{i}+1
\end{aligned}
$$

The time index takes the values $t=1087, \cdots, 19013$, and 1991, $\cdots 1995$. Following Galloway, Iete and Roden (1907), we estimate lagered regression equations between

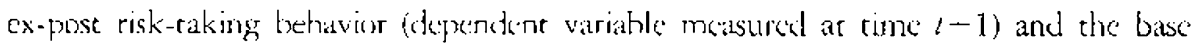
periods' ex-ante explanatory variables (measured at (ime i). 'Ilke time lay between

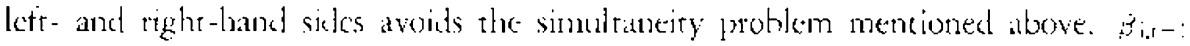
represents the systematic (narket-related risk of the bask $i$ at time $t+1$, and $\sigma:\left(\varepsilon_{1, t}\right.$, ) represents the unsystematic (non market-related) risk of the bank $i$ at time $1+1$. Both of them are estimated from the one-factor market model using the daily stock returns of bank $i$ with the matket portfolio represented by S\&P 500 .

'To cxamine the refationship berween risk and bank protitability, or wherher the banks have so-called mural hazard jncentives in their risk-taking behavior, we estimate the following cquations. First, we regress the return on assets on enly with respect to the risk measures, $\beta$ and $(\sigma)(\varepsilon)$, and the return on S\&P 500 , controlling for the effect of the overall market conditions on weh individual bank's performance. Then we regress the return on assets, including all rhe explinatory variahles cmployed in the estimation of the risk-taking incentives. 


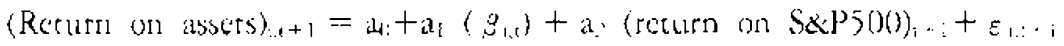

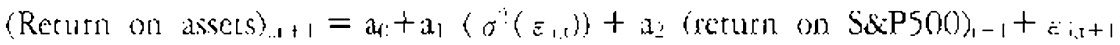

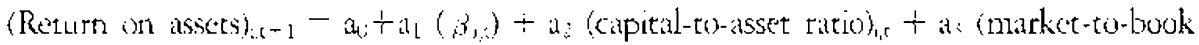

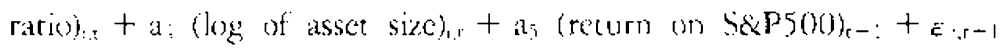

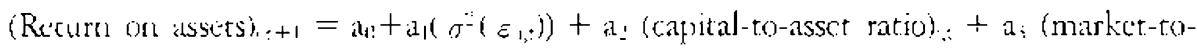

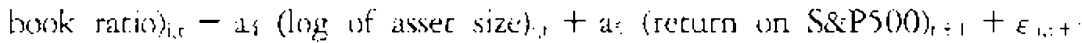

\section{EMPIRICAL RESUJ.TS}

\section{Results Based on the Full Sample}

The results for estimutiry the relationship between insides ownershyjs and risk-taking, coutation 1 and 2, for the two different regulatory regimes are presented in Talble 2. As shown in the second column of Table 2, no coxfficients are statistically significant for Lxoh the 1987-1990 and 1991-1995 perioxts, when risk is interpreted as unsystematic risk. We heneceforth ignore this interpretation and tixus on systematic risk. Regardiogy the hypothesis of the study, the coxffeicnt on insider uwnership is significantly positive wer the petiod $1987-1900$. when risk is measured by the systematione, indicaring that the banks' sysernatic risk-taking incentives hecome significantly greater as the insider or manareral ownership riscs, when regulations are loose. For control variables,

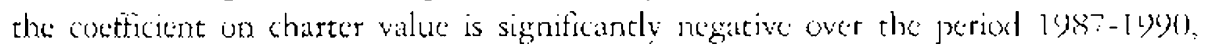
indicating that the banks with lester chancer values have significantly greater risk-taking incentives when regulations are loose, consistine with the findings of Keeley (1990), Cralloway, Lee and Roden (1997), and Cobenoyan, Cooperman and Regiser (1999).

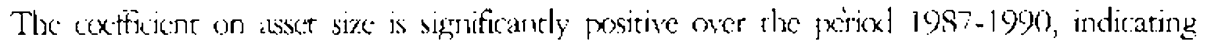
the existerne of Inoral bazasd incentives associated with the too-big-to-fail hypothesis diting the period of deregulation. (ontrary to expectation, the coefficient on capital-to assce ritio is insignificantly posicive.

Table 3 presents the results fur tle association of the degree of risk-taking with prufitatility of banks. Wo are interested in examining the coefficient on the systematic rish: 3. since in the former test, we obsened a significantly positive relationstup berween the degrex ot irsicker ownership and systematic risk. Indeed, Table 3 shows a significantly

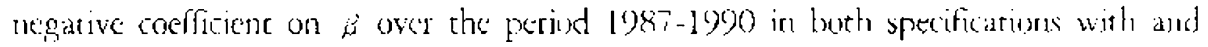
withour conced variables, suggesting that the higher the systematic risk, the worse the proticability of hanks. 'Ihis result may sugegest that the hanks pursud perverse tisky stritegrices over the period of dercerulation.

Now, let's turn to the results for the period of tightered regulation (190)1-1995). Firsc, regarding the results for the banks' risk-taking incentives, Table 2 shows that the greater systematic rish-caking incentives for higher insider-nuncrship banks than 
lower insider-ownership banks no longer appear over the periexd of tightened regulation. This result, of coursc, is expected to have resulted from the tightened regulation over the latter period. Particularly, risk-based deposit insurance premiums introduced in 1993 mill deserve all, or at least part of the credit. This is because by making banks' cost of funds properly sensitive to the banks' asset risk (i.c. by charging higher insurance premiuns for higher risk), risk-based deposit insurance premiuns is expected to reduce banks' risk-taking incentives. For control variables, the significantly positive relationship between systematic risk and asset siac ouct the periods of deregulation is no longer observed. These results again ofter support for the etlectiveness of regulatory reforms, because they reduce the previously found associations supporting the existence of moral hazard incentives among these variables in banking liferature.

Regarding the relationship haween systemacic risk and profitatility of the banks uver the latter period, Table 3 shows that the perverse risk-taking incontives over the period 1987-1990, reflected by the significantly negative relation between the retum on asset and $\beta$, becume weater and the assuciation has improved after regulatory reforms, as indicated by a marginally significant (at around $15 \%$ significance levels) and positive cosficient on $\beta$. That is, after regulatory reforms, high current riskiness became herer associared with the subseguent gond pertormance compared to pre-reforms periox.

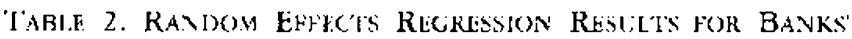 RISK-ISIKING; LNGENTIVES}

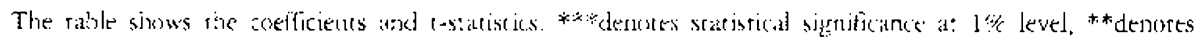

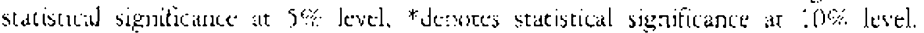

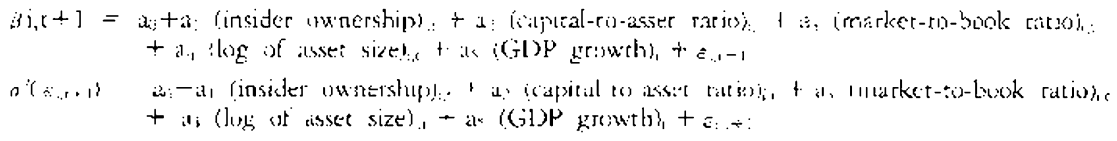

\begin{tabular}{|c|c|c|c|c|}
\hline \multirow{2}{*}{ Dependent variable } & \multicolumn{2}{|c|}{$\beta_{1,1}:$} & \multicolumn{2}{|c|}{$\sigma \ddot{q}\left(\varepsilon_{i,:+1}\right)$} \\
\hline & $198: \sim 1990$ & $1991 \sim 1995$ & $1087 \sim 1000$ & $1991-1995$ \\
\hline \multirow{2}{*}{ Intercepte } & (1) & 1).254)|3 & $0.0(0.7 ?$ & 0.0050 \\
\hline & $(0,3,3)$ & $(0.62)$ & $(0.153$ & $(0.08)$ \\
\hline \multirow{2}{*}{ Insilder (мжлегship } & $0.00927^{\times *}$ & (i). (1) sisis & 0.0283 & $0.019 ?$ \\
\hline & $i 2 .\{13$ & $\left((1,)^{\prime}\right)$ & $(0.1) \times$ & $(0.76)$ \\
\hline \multirow{2}{*}{ (apical-co-asset ratio) } & (i. 1811 & 0.5418 & -0.0237 & $0.0(0) 1$ \\
\hline & (1) $7 \cdot 2 \cdot 2$ & $(1) 6$. & $\{-0.56\}$ & 10.1 .43 \\
\hline \multirow{2}{*}{ Mirket-tu-ismek ratic; } & -0.912 & $0.0>28$ & $0.010) 66$ & $0.0412 ?$ \\
\hline & $(-i, 73)$ & $(0.4 \bar{i}\rangle$ & (0. 1ㄴ) & $(0 .-40)$ \\
\hline \multirow{2}{*}{ log of assec size } & $0.36188^{* *}$ & $(0.1) 270$ & 0.0012 & $-(3.0910$ \\
\hline & $(391)$ & $(0.7)$ & $(0,23)$ & $\{-(1)\{1\}$ \\
\hline \multirow{2}{*}{ (il)e growet } & -1.2109 & -0.9143 & -0.0563 & (1).0381 \\
\hline & $(-0.61)$ & $(-0.56)$ & $(-\{j .1 i)$ & $(0.19)$ \\
\hline Adjuseced R & 0.32 & (1).21 & 0.17 & 0.23 \\
\hline
\end{tabular}




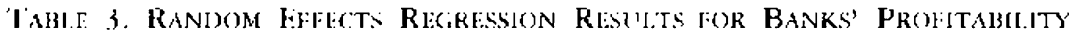

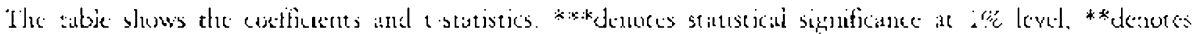

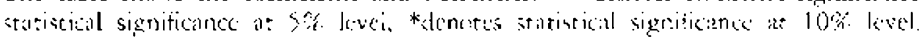

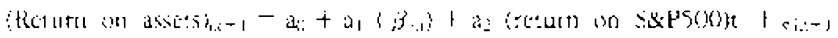

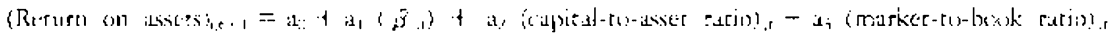

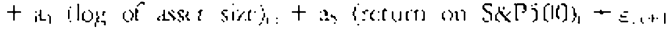

\begin{tabular}{|c|c|c|c|c|}
\hline & $1987-1990$ & $1987 \sim 1990$ & $1991 \sim 1995$ & $1991 \sim 1995$ \\
\hline forecespr & $\begin{array}{c}0.9662^{\circ \times} \\
(! 5.82)\end{array}$ & $\begin{array}{c}0.8269^{n+2} \\
(1 \cdot 1.65)\end{array}$ & $\begin{array}{c}1.100\left(2^{\circ}\right. \\
117.23 j\end{array}$ & $\begin{array}{c}0.5\left(3 ?^{3 * 1 *}\right. \\
(15.1:)\end{array}$ \\
\hline$?$ & $\begin{array}{c}-0.27611^{\mathrm{k}} \\
1-2.16 \mathrm{i}\end{array}$ & $\begin{array}{l}-0 . \leqslant \mid 87^{* *} \\
(-1.49)\end{array}$ & $\begin{array}{l}0.1175 \\
(1.52)\end{array}$ & $\begin{array}{l}10.21018 \\
(1.56)\end{array}$ \\
\hline (apital ro asser ator) & & $\begin{array}{l}0.1792 \\
0.369\end{array}$ & - & $\begin{array}{l}(1.2210) \\
(11.56)\end{array}$ \\
\hline Matiker-to-b(isk ristlis & - & $\begin{array}{c}0.5528^{\circ} \\
11.65\}^{\circ}\end{array}$ & - & $\begin{array}{l}0.3 \geqslant 8 \% \\
1.04\}\end{array}$ \\
\hline Iog: it asset size & - & $\begin{array}{l}1.01025^{\circ} \\
11.63)^{\circ}\end{array}$ & & $\begin{array}{l}0.6165 \\
10.351\end{array}$ \\
\hline Return un $(x \times p s(x)$ & $\begin{array}{l}13.13801 \\
0(1) 6(6)\end{array}$ & $\begin{array}{l}0.0: 2: \\
(0.01)\end{array}$ & $\begin{array}{l}\text { 1). } 13\} 18 \\
\text { (1.02) }\end{array}$ & $\begin{array}{l}\text { (3). }(5.25 \\
\text { (0.85) }\end{array}$ \\
\hline Adje!ssa: $\mathrm{R}^{\prime}$ & 0.16 & 0.18 & $0 . .4$ & 0.21 \\
\hline
\end{tabular}

Taken together, in terms of only addecssing the ownerimanager agency problem, the resules in table 2 and 3 strongly suggest that in years of dercyulation, the own-

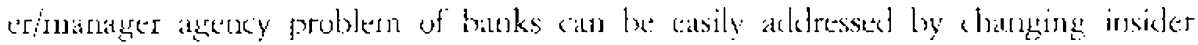
looldings or ownership structure that may be assoxiated witl incteased fisk. But this policy should be taken sery cautiously, sime the banks seem to take on more than enough risk in yeurs of deregulation that may ultimatcly increase the probability: of tailure of the banks. This might suggess that the increase in insider holdings to address the ow ner/manager igency problem should to associatext with dower monitoning of the banks risk-taking behavior.

\section{Results Rased on the Partitioned Sample ('lest for Corporate-Control Hypothesis)}

To exaninc whether there are any differences in the relationships between ownership strucrure, risk-taking, and profitability among lower insider-ownershop wroup ws. bightuer ones, we partition the full sample into these wo groups and run the same regressions as in 4.1 , including the dunnmy varbable for the leswer insider-benership variathe, D.. Lach year, the full sample is partitionect at the median for the insider-ownorship varialle. First, we estimate the following nwo equations wer the periont 1987-1990.

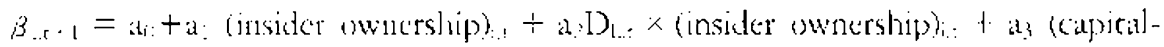

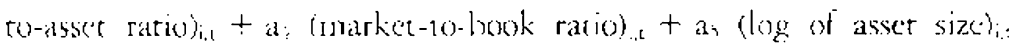

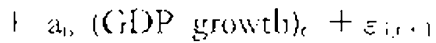




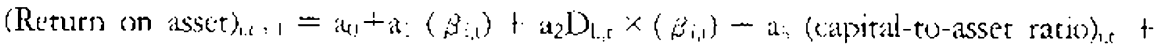
$d_{1}$ (market-to-book ratio) $)_{e}-a_{i}$ (log of asset size). $+a_{i}$ (return on $\operatorname{SeP} 5(0)) \ldots: \tau i, \ldots 1$

Where $t=198 ?, \cdots, 1990$, and $1_{L:}=1$, if bank $i$ is in the lower insider-ownership group at time $t$ and 0 otherwise

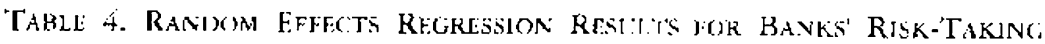 liverntrves and PROHTAEHITY}

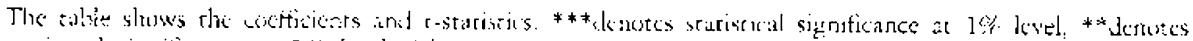

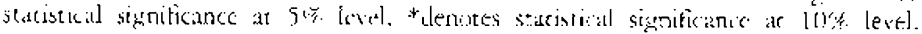

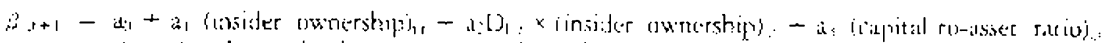

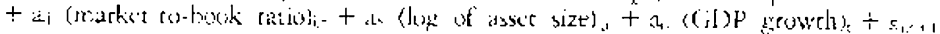

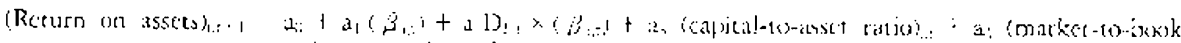

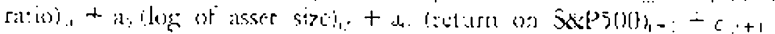

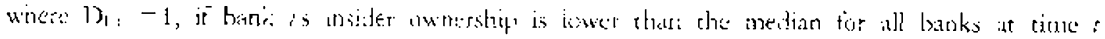
las? ..... |wy

\begin{tabular}{|c|c|c|}
\hline Dependent variahle & & (Return oul asset $)_{i, t-1}$ \\
\hline intertept & 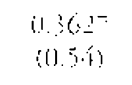 & $\begin{array}{c}0.9216^{\circ \times 0} \\
(15.21)\end{array}$ \\
\hline Jnsicter cuaverstalp) & $\begin{array}{l}0.0826 \\
\text { (1.35: }\end{array}$ & - \\
\hline 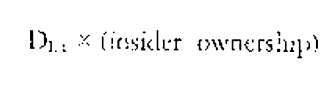 & $\begin{array}{l}\left(0,02^{+\times 1}\right. \\
(203)\end{array}$ & . \\
\hline 2 & - & $\begin{array}{l}-\left[1.1652^{\circ}\right. \\
(-1.70)\end{array}$ \\
\hline $\mathrm{D}_{\ldots, ., y}$ & - & $\begin{array}{l}-\left\{1 .\{1: 2\}^{* *}\right. \\
(-1.89\})\end{array}$ \\
\hline Capital-ro-dssat ratus & $\begin{array}{l}0.163= \\
10.57 ?\end{array}$ & $\begin{array}{l}\text { (3. } 1528 \\
\text { (i).4i) }\end{array}$ \\
\hline Marke-c-ar-bikek ratrios & $\begin{array}{r}-(1.8238 \\
(.22)\end{array}$ & $\begin{array}{l}0.4923 \\
11.62 ?\end{array}$ \\
\hline 1.09 of asset sizc & $\begin{array}{l}(3.116)^{* * *} \\
(3.62)\end{array}$ & $\begin{array}{c}-\{.0(\})\}^{\circ} \\
(1.0 .\})\end{array}$ \\
\hline (il)e grewith & $\begin{array}{l}-1.1593 \\
(-67,9)\end{array}$ & - \\
\hline Kerurn ox Sepsik) & & $\begin{array}{l}11.19621 \\
10.7[1 ;\end{array}$ \\
\hline Adjust $\mathrm{R}^{2}$ & (). (i) & 0.23 \\
\hline
\end{tabular}

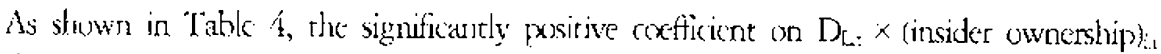
with respect to $\beta$, and the significanty negative cokfficiont on $D_{\mathrm{L} . t} \times\left(\beta_{\mathrm{ir}}\right)$ with respect to return on assces, indicate that the positive relationship between insider ownership and risk-taking and the negative relation between the risk-taking and profitability 


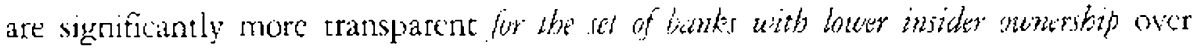

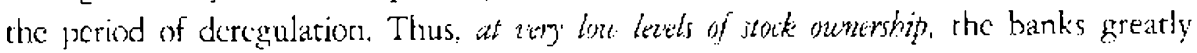
increase risk, though ultimately umprofitable risk, as the level of insider ownership rises over the period of deregulation.

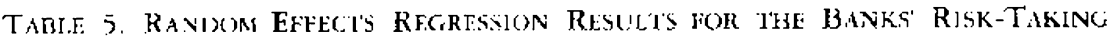

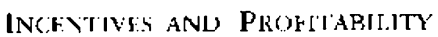

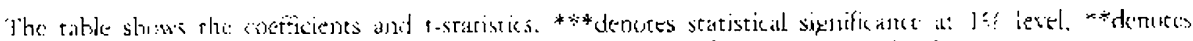

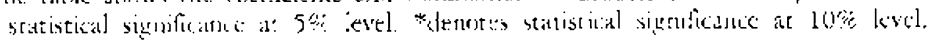

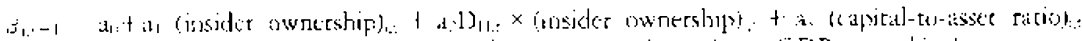

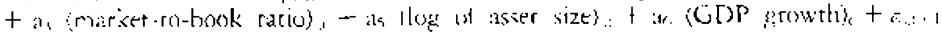

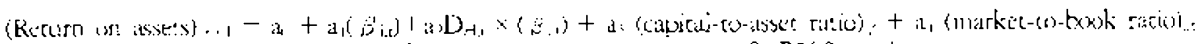

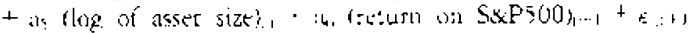

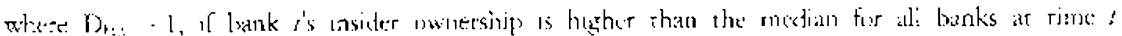
$t=19 y 1 \ldots . . .194)$

\begin{tabular}{|c|c|c|}
\hline Dependens variable & $B \ldots-1$ & (Return on asst: $)_{2,1-\text { : }}$ \\
\hline Intejitpt & $\begin{array}{l}0.3124 \\
010.539\end{array}$ & $\begin{array}{c}(1.9782 * * * \\
116.111)\end{array}$ \\
\hline Iusider ownership: & $\begin{array}{l}(10,25 \\
(0,72 ?\end{array}$ & - \\
\hline 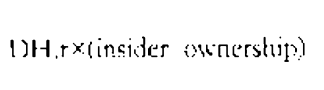 & $\begin{array}{l}(0.0) 3: 2 \\
(1.0219\end{array}$ & \\
\hline$\beta$ & - & $\begin{array}{l}0.23,8\} \\
\{1,\{8\}\end{array}$ \\
\hline$D_{11,1} \therefore \beta$ & & $\begin{array}{l}0.0 \% 8 \\
(1.32)\end{array}$ \\
\hline Cinpiral-tu-asset ratiou & $\begin{array}{l}0.38 ? 1 \\
(1.08)\end{array}$ & $\begin{array}{l}0.199 .5 \\
\text { (4).52) }\end{array}$ \\
\hline Markut ubook ratu & $\begin{array}{l}0.0485) \\
(0.50)\end{array}$ & $\begin{array}{l}\text { 1).28? } \\
(1.16 !\end{array}$ \\
\hline Ligz uf is isiet sizc: & $\begin{array}{l}\{1,\{1\}\} \\
\{0.8 ?\}\end{array}$ & $\begin{array}{l}-(1) .062 \bar{i} \\
(-6) \dot{4} \vdots)\end{array}$ \\
\hline (iI) $\rangle^{\text {garimeh }}$ & $\begin{array}{l}-(8.382) \\
(-(0.4))\end{array}$ & - \\
\hline 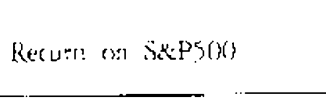 & & $\begin{array}{l}1) .0628 \\
(1.01)\end{array}$ \\
\hline Adjust $R^{:}$ & (1). I ti & 0.22 \\
\hline
\end{tabular}

This result is consistent with the corporate-control bypothesis as suggested by Gorton and Rosen (1995). The comporate-cuntrul hypothesis states that during perioks of decline fur the banking industry, bad managers can becone enerenches by holding low levels 
of stock uwnership. In such an cnvirunment, bad managers can take on excessive, but ultimatcly unprofitahle, risks in an attompt to mislead outside stockholders into thinking that they are good managers. Herc, we find some evictence for the corporate-concrol hypothesis in the sample priot of the lare 1980s, characterized by relative deregulation, increased competition, and declining profitability in the barking industry.

To complete the test for the corporate-control hypothesis, we estimate the above cquations, including the dumny variable for the higher insider-ownership variable, $\mathrm{D}_{\mathrm{H} . \mathrm{l}}$, over the period 1991-1995, duting which the banking industry experienced rightened regulation, increasing profitability and chatrer valuce, and cconomic expansion. In the estimation for this period, we explicitly include the dummy variable for the higher insider-ownership group, $\mathrm{I}_{31 \text {. }}$ for convenience. This is beciuse the corporate-control hyporhesis focuses on the behavior of managers with large stock holdings when the above conditions characterizing the decline of the banking industry, such as in the 1980s, disappear, and predicts that manager-ownd banks will congage in profitable risk-taking. 'Tahle 5 presents somewhat consistent results with this prenuise. as indicated by a positive coefficitent on $D_{11, c} \times$ (insider ownership)i, and $D_{H_{1}:} \times \beta_{1.3}$ ), even though the latter is insignificant. That is, at bigh lewels of atok atomerbip, the banks secon to ergatge in profitable risk-taking as the level of insider owaetship rises.

Overall, rhe results from the partitioned samples proside stronger evidence for the hypotheses for banks ar very low levels of stock ownership, and we maly have to give stronger policy suggescions to those lanks than thuse made in Section 1.1 .

\section{CONCLUSION}

We examine how the relationshipg letween bark: ownership structure and risk-taking may lo differently affocted by different regulatory regines in the U.S. banking industryr. We find that higher insider-ownership banks have greater risk-taking incentives than lower insider-ownership lanks over $1987-19 \%$ ) (a period of relative deregulation and decline of the UJS. banking industry). whon we represent risk-taking by systematic risk. However, this greater systematic risk-raking is unptofitable, indicating that the banks pursued perverse risky stritegics in the lite 1980 s, as suggested by the mord-hazard hypothesis in the banking literature. But we find that systematic risk-taking incentives of higher insider-ownershjy hanks ws. lower insider-ownership banks disippeared, and that the association betwecn risk-taking and profirahility improved over the period of tightened regulation (1991-1995). These resules may offer same evidence for the effectiveness of regularory reforms in the U.S. banking industry beginning aruund 1991

In the est for the partitioned sample between loner insider-ownership banks ws. higher ones: we find that the positive relation between the insider ounership and risk-taking, and the uegative relation between the risk-taking and profitability, are significantly muse transparent for the set of banks with loner inster ontnership over the 


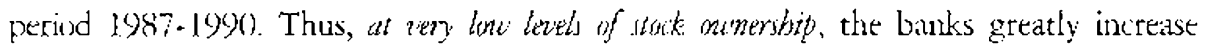
risk, though ultimatcly unproficable risk, as the level of insider ownership rises over the period of deregulation and decline of the hanking industry. This result is consistent with the corporate-control hypothesis. Over the period 1991-1995, we also find that at high letels of stock ountrship, the banks scem to cngage in profitable risk-taking as the level of insider ownership rises, as predicted by the corporate-control bypothesis.

Overall, in terms of only addressing the ownerimanager agency problem, these results strongly suggest that in years of deregulation, the ownerimanager agrency problem of banks can be easily addressed by changing insider holdings or uwnership structure that may be associated with increased risk. But this policy should be taken very cautiously, since the banks seem to take on more-than-enough risk in years of deregulation, which may ultimately increase the probability of failure of the banks. 'This might suggest that the increase in insider holdings to address the ownerimanager agency problem shoukl be associated with closer monicoring of the banks' risk-taking bchavior. Ihis policy sugesestum sboukd be griven greater cmphasis on banks wirh very low levels of stock ownership.

\section{REFERENCES}

Benstorn, G., R. Fisenbeis, P. Horvity, F. Kanc, and G. Kaufman. 1986 . Perspletives

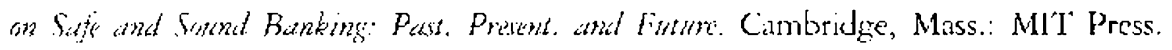

Cabcayan, A. S., Cooperman, E.S., and Register, (. A. 1999. Owoteship Structure, Charter Value, and Risk-tiking Betwiver for Thisfts. Fimancial Manakment 28: 43-60).

Chen. A. H., Cornert, M. Mazumdar, S., and Tehcranian. H. 1999. An Empirical Anatysis of the Elfects of the FIICIA of 1991 on Commercial Banks. Rerearos in Finanie 17: $41-64$.

Chen, $A$. II. and Mervilc, L. 1986. An Analysis of Divestiture Fffects Resulring

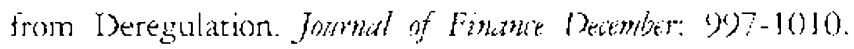

Demsers, R.S., Saidenlerg, M.R, and Strahan P.F. 1997. Agency Problems and Risk 'Taking at Banks. Staff Reprint No.29. New York: Federal Reserve Bank of New York.

Demsex, H. and Iethn, K. 1985. The Structure of Corporate Ownership: Causes and Consequences. Joumal of Politrial Economy 93:1155-77.

Denis, D. 2(ro1. Twenty-five Years of Corpusate Gurernance Rescarch...ind Counting. Retikt: of Financiat Econsmiti 10: 19l-2]2.

1.sty, 13.C. I9)?a. Organicational from and Risk-taking in the Savings and Loan Industry. Jourral of Finumital liconnmic it: $25-56$.

Galloway, 'T.M., Lee, W.B., and Roxden, D.M. 1997. Banks' Changing Incentives and Opportunities for Risk Taking. Joumal of Banking and Finant 21: 509-27.

Gurton, G. and Rosen, R. 1995. Corporate Control, Portfolio Choice, and the Decline of Banking. Journal of finumie 5: $137 ?-1420$. 
Holderness, C. G. 2003 . A Survey of Blockholders and Corporace Control. Eommic Polity Rarime c) $51-64$.

Hughes, J. P., Iang, W., Mester, T., M(x)n, C. G., Pagano, M. 2003. Do Bankers Sacrifice Values to Build Fonpires? Joumal of Banking and Finance 27.

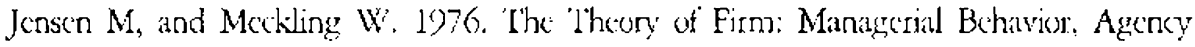
Costs and Owncrship Structure. Jommal of Finanial Eomonitir 3: 305-60.

McConnel, f. and Servaes, H. 1990. Additional Lvidence on Lquity Ownership and

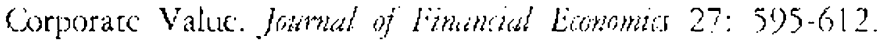

Mork, R. Shleter. and Robert Vishny. 1988. Management Ownership and Market Valuation: An Fmpirical Analysis. Jramal of Financial Fonnomici 20: 203-316.

O'I lara, M. and Staw. Wi. 1990. Deposit Insurance and Wealth Effects: The Value of Bcing "Too Big to Fail". Jommat of lincme 5: 1587-1600.

Oshornt, D). K. and Itee, S. W. 2001. Effects of Leposit Insturance Reform on Moral

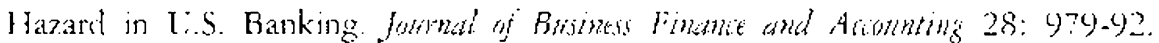
Saunders A. Strock. F., and Travlos V.G. 1990 . Ownership Structure, Deregulation, and Bank Risk Taking. Joumid of Finomic 2: 643-54.

\section{ENDNOTES}

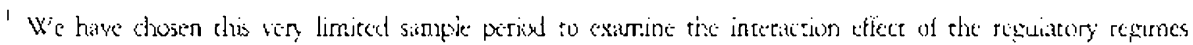

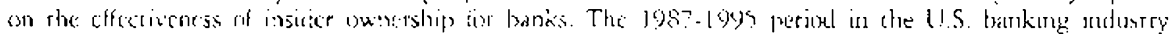

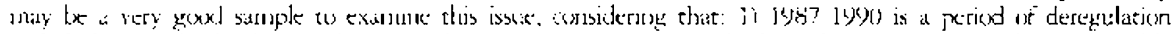

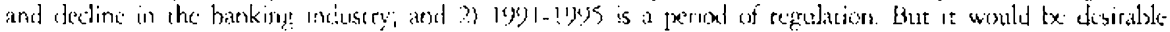

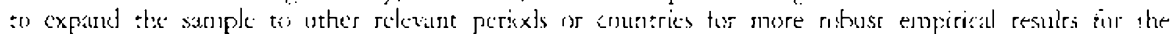
issue. 